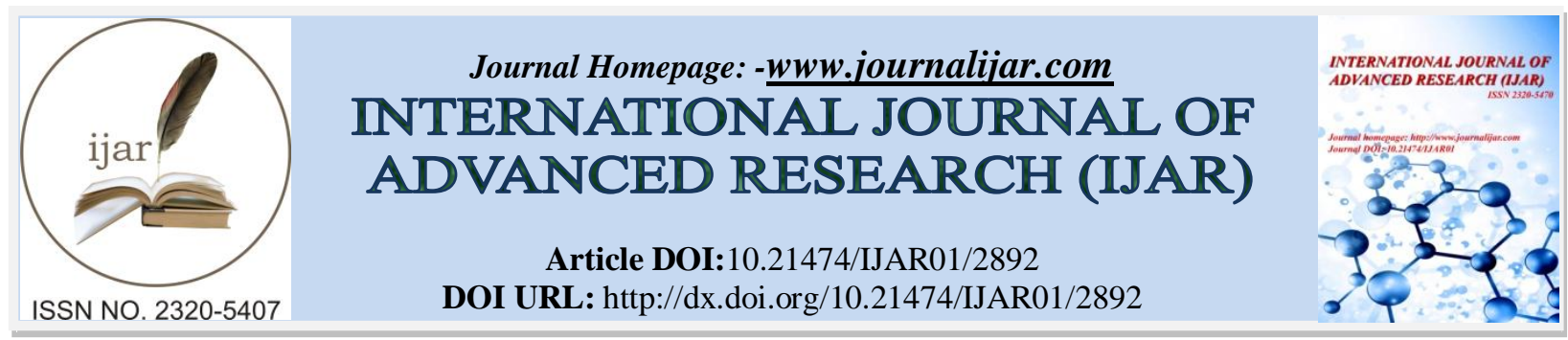

RESEARCH ARTICLE

\title{
LEVEL OF EDUCATION AMONG DIABETIC PATIENT REGARDING DIABETIC FOOT IN MAKKAHPOPULATION
}

\author{
Dr. Mohammad Amin K Mirza MD FACS ${ }^{1}$, Dr. Hassan Adnan Bukhari MD. FACS ${ }^{1}$, Dr. Hesham \\ Abdulaziz Bahadur ${ }^{2}$, Dr. Mawadda Abdullah Hariri ${ }^{2}$, Dr. Ahmad Sabir Albeshri ${ }^{3}$, Dr.Israa Atif Kalantan ${ }^{4}$ \\ and Dr. Abrar Khalid Khalil ${ }^{5}$. \\ 1. Assistant Professor of Surgery Department of Surgery Faculty of Medicine Umm Al-Quraa University. \\ 2. MBBS -Umm Al-Quraa university, Makkah, Saudi Arabia \\ 3. Neurosurgery resident $-\mathrm{NGH}$ - Jeddah, Saudi Arabia \\ 4. Medical resident - KFSC, Saudi Arabia \\ 5. Radiology resident- Al-Noor Hospital, Saudi Arabia
}

\section{Manuscript Info}

Manuscript History

Received: 22 November 2016

Final Accepted: 23 December 2016

Published: January 2017

Key words:-

Diabetic foot, Knowledge, foot care, complications

\section{Abstract}

Background: As many of diabetic complications, diabetic foot are avoidable however proper education is essential as it leads the patient to be aware of the problem and its prevention which can save the patient's feet from amputations.

Objectives: To assess knowledge of diabetic patients regarding foot care and its determinants.

Subjects and methods: A retrospective study has been carried out to compare diabetic patients without foot problems to those who had them. It included all diabetic patients from four major hospitals in Makkahwith and without Diabetic foot from Makkah city. A studyspecific questionnaire was designed included general information, level of education, and added questions at the end to measure the knowledge.

Results: The study included 392 patients. Their age ranged between 13 and 90 years $(53.6 \pm 13.3$ years $)$. Almost two-thirds of the patients were males (62\%). Majority were Saudis (86.1\%). Type II diabetes was reported by $52.1 \%$ of the patients. Regular compliance with diabetic clinic/center was mentioned by $65 \%$ of them. Adherence to antidiabetics was reported by majorities $(87 \%)$. History of feet wound lasted 3-4 weeks was reported among $42.9 \%$ of diabetic patients. Where is a history of amputation was reported among $20.9 \%$ of them. The mean knowledge score was 5.6 out of 10 (56\%). Good knowledge regarding foot care was higher among younger patients ( $\leq 30$ years) compared to older patients $(>50$ years $(68 \%$ versus $41.4 \%, \mathrm{p}<0.001)$. Majority of postgraduate patients (87\%) compared to $34.7 \%$ of illiterate patients had good knowledge regarding foot care knowledge, $\mathrm{p}<0.001$. The highest level of good knowledge regarding foot care was reported among patients with onset of diabetes between 11 and 20 years (70\%) whereas the lowest level was reported among those with onset after 20 years $(46.2 \%), \mathrm{p}=0.011$. Good foot care knowledge was more reported among type 1 than type 2 patients $(73.3 \%$ versus $51.7 \%, \mathrm{p}<0.001)$. Regular compliance with diabetic 
Clinic/center was accompanied with higher knowledge level, $\mathrm{p}<0.001$. Also, adherence to anti-diabetics was accompanied with higher knowledge level, $\mathrm{p}=0.011$.

Conclusion: Knowledge of diabetic foot care in Makkah is moderate $(56 \%)$, younger, more educated, type 1 diabetic patients and those who attended diabetic clinics regularly and being more compliant with antidiabetics were more knowledgeable. Heath education programs are recommended particularly to older and less educated patients. In addition, patients should be encouraged to attend diabetic clinics regularly.

Copy Right, IJAR, 2016,. All rights reserved.

\section{Introduction:-}

Diabetes mellitus is one of the most common health problems affecting all age groups worldwide and was estimated to be $2.8 \%$ in 2000 and $4.4 \%$ in $2030 .{ }^{1}$ The prevalence of diabetes in the Medicare population may be one-third higher than previously estimated. ${ }^{2}$ Overall, approximately $8 \%$ of diabetic Medicare beneficiaries have a foot ulcer and $1.8 \%$ has an amputation. These prevalence rates are further elevated for the subset of beneficiaries with lower extremity peripheral artery disease. ${ }^{2}$

The prevalence rates for foot ulcer and lower extremity amputation among diabetic Medicare beneficiaries vary dramatically by geographic region. More than 16 million people in the United States (U.S.) have diabetes mellitus. The prevalence of diabetes among those over 65 years of age was last estimated by the Centers for Disease Control and Prevention (CDC) using 2008 data from the National Health Interview Survey. It is about 19.9 percent among those ages 65 to 74 and 17.1 percent among those more than 75 years of age. These estimates are based on selfreports and are thought to underestimate the true prevalence by one-third. ${ }^{2}$

The prevalence of diabetes in Saudi Arabia was 34.1\% in males and 27.6\% in females (mean age is 55 years),such high prevalence make diabetes an endemic and stands as a major health issue in our healthcare systems and society.

One of diabetes common and serious complications is diabetic foot problem, which is a major cause of morbidity and mortality in patients with diabetes. Infection, ischemia and neuropathy are all contributing to produce tissue necrosis ${ }^{3}$.

Studies showed that up to $10 \%$ of patients with diabetes would develop a foot ulcer sometime during their lives 4 and it is the most common cause of non-traumatic lower limb amputation and precedes $85 \%$ of the cases ${ }^{5}$.

The prevalence of diabetic foot problems differs between countries in the world ${ }^{5}$. In Saudi Arabia, DF wasprevalent in $13.5 \%$ of the diabetic patients referred to the nephrology clinic ${ }^{6}$; several factors make this prevalence higher as compared to the West including patient education.

As many of diabetic complications, diabetic foot are avoidable however proper education is essential as it leads the patient to be aware of the problem and its prevention which can save the patient's feet from amputations. Educators including physicians usually educate their patients on controlling their blood sugar either with insulin or diet mainly and rarely about the feet care.

As prevention requires knowledge it also needs change in behavior. To assess our ability to effect change in behavior we need to measure not only knowledge but also understanding the change of behaviors. This study was carried out using a structured questionnaire to assess the knowledge among diabetic patients regarding feet care.

\section{Subjects and Methods: -}

A retrospective study has been carried out to compare diabetic patients without foot problems to those who had them. It included all diabetic patients with and without Diabetic foot from Makkah city, there was no age limit, the study excluded non-Makkah residents (pilgrims), non-diabetic. 
A study-specific questionnaire was designed included general information, level of education, and added questions at the end to measure the knowledge.

Ethical approvals from Um AlQura University and the ministry of health in Makkahwere taken to collect the data from four major hospitals in Makkah (AL Noor specialist hospital, King Faisal specialist hospital, Hera general hospital, king Abdulaziz hospital). Then, the questionnaires were distributed to patients from the general population with diabetes and from those attending and following in a diabetic center in Makkah. Patients were grouped into two categories; 1) diabetics without foot problems, and 2) and those with foot complications. Then data was collected and analyzed using (SPSS, version 22).

\section{Results: -}

The study included 392 patients. Their age ranged between 13 and 90 years (53.6 \pm 13.3 years). Almost two-thirds of the patients were males (62\%). Majority were Saudis (86.1\%). More than one-quarter of them were professionals (26.4\%), retired $(29.4 \%)$ or not working $(26.1 \%)$. Almost one third of them $(33.5 \%)$ were at least university graduated whereas $18.4 \%$ of them were illiterates.

Table 2 summarizes the diabetes-related characteristics of the participants. Among majority of the participants (84.9\%), diabetes was diagnosed after age of 20 years. Type II diabetes was reported by $52.1 \%$ of the patients. Regular compliance with diabetic clinic/center was mentioned by $65 \%$ of them. Adherence to anti-diabetics was reported by majorities $(87 \%)$.

History of feet wound lasted 3-4 weeks was reported among $42.9 \%$ of diabetic patients as shown in figure 1 whereas history of amputation was reported among $20.9 \%$ of them. Figure 2

Figure 3 showed that $78.3 \%$ of the patients knew that they should reach their sole of the foot and see if there is any problem, $42.9 \%$ knew that theyshould daily examine their feet. It was found that $90.3 \%$ of them recognized that washing feet should be daily, 54.8\% of them recognized using warm water for that. Almost half of patients (46.9\%)know that a clean towel should be used to dry their feet after washing it. Less than half of them (48.7\%) know that they should cossed their legs on sitting. Around 54.6\% of the paticipantsknew thatthey should usea cream to moisturize their feet, $35.5 \%$ of them know that it should be used between their toes. We found also that $74.0 \%$ knew that they should cut nails by themselves, $35.2 \%$ knew the proper way of cutting nails.

The mean knowledge score was 5.6 out of $10(56 \%)$. From table 3, it has been shown that good knowledge regarding foot care was higher among younger patients $(\leq 30$ years) compared to older patients $(>50$ years $(68 \%$ versus $41.4 \%, \mathrm{p}<0.001$ ). Majority of postgraduate patients (87\%) compared to $34.7 \%$ of illiterate patients had good knowledge regarding foot care knowledge, $\mathrm{p}<0.001$. Other demographic factors (gender, nationality, and occupation) were not significantly associated with foot care knowledge.

The highest level of good knowledge regarding foot care was reported among patients with onset of diabetes between 11 and 20 years $(70 \%)$ whereas the lowest level was reported among those with onset after 20 years (46.2\%), $\mathrm{p}=0.011$. Good foot care knowledge was more reported among type 1 than type 2 patients (73.3\% versus $51.7 \%, \mathrm{p}<0.001)$. Regular compliance with diabetic clinic/center was accompanied with higher knowledge level, $\mathrm{p}<0.001$. Also, adherence to anti-diabetics was accompanied with higher knowledge level, $\mathrm{p}=0.011$. There was no significant difference between patients with history of foot wound lasts 3-4 weeks/amputation and knowledge of diabetic foot care. Table 4 
Table 1:-Demographic characteristics of the participants

\begin{tabular}{|c|c|c|}
\hline & Frequency & Percentage \\
\hline $\begin{array}{l}\text { Age }(\text { years })(\mathbf{n}=\mathbf{3 8 9}) \\
\leq 30 \\
31-50 \\
>50\end{array}$ & $\begin{array}{l}25 \\
120 \\
244\end{array}$ & $\begin{array}{l}6.4 \\
30.8 \\
62.8\end{array}$ \\
\hline $\begin{array}{l}\text { Range } \\
\text { mean } \pm \text { SD }\end{array}$ & \multicolumn{2}{|c|}{$\begin{array}{c}13-90 \\
53.6 \pm 13.3\end{array}$} \\
\hline $\begin{array}{l}\text { Gender } \\
\text { Male } \\
\text { Female }\end{array}$ & $\begin{array}{l}243 \\
149\end{array}$ & $\begin{array}{l}62.0 \\
38.0\end{array}$ \\
\hline $\begin{array}{l}\text { Nationality }(\mathbf{n}=\mathbf{3 8 1}) \\
\text { Saudi } \\
\text { Non-Saudi }\end{array}$ & $\begin{array}{l}328 \\
53\end{array}$ & $\begin{array}{l}86.1 \\
13.9\end{array}$ \\
\hline $\begin{array}{l}\text { Occupation }(\mathbf{n}=360) \\
\text { Professionals } \\
\text { Students } \\
\text { Military } \\
\text { Retired } \\
\text { Manual } \\
\text { Not working }\end{array}$ & $\begin{array}{l}95 \\
15 \\
15 \\
106 \\
35 \\
94\end{array}$ & $\begin{array}{l}26.4 \\
4.2 \\
4.2 \\
29.4 \\
9.7 \\
26.1\end{array}$ \\
\hline $\begin{array}{l}\text { Education } \\
\text { Illiterate } \\
\text { Primary } \\
\text { Intermediate } \\
\text { Secondary } \\
\text { University } \\
\text { Postgraduate } \\
\end{array}$ & $\begin{array}{l}72 \\
74 \\
47 \\
67 \\
108 \\
23 \\
\end{array}$ & $\begin{array}{l}18.4 \\
19.0 \\
12.0 \\
17.1 \\
27.6 \\
5.9\end{array}$ \\
\hline
\end{tabular}

Table 2:- Diabetes-related characteristics of the participants

\begin{tabular}{|l|l|l|}
\hline & Frequency & Percentage \\
\hline Age of diabetes onset in years $(\mathbf{n = 3 8 5})$ & 28 & \\
$\leq 10$ & 30 & 7.3 \\
$11-20$ & 327 & 84.9 \\
$>20$ & & \\
\hline Type of diabetes $(\mathbf{n}=\mathbf{3 8 6})$ & 45 & 11.7 \\
Type I (n= & 201 & 52.1 \\
Type II & 140 & 36.2 \\
Unknown & & \\
\hline Regular compliance with diabetic clinic/center $(\mathbf{n}=\mathbf{3 8 9})$ & 253 & 65.0 \\
Yes & 136 & 35.0 \\
No & & \\
\hline Adherence to anti-diabetics & 341 & 87.0 \\
Yes & 51 & 13.0 \\
No & & \\
\hline
\end{tabular}

Table 3:-Association between knowledge of foot care and demographic characteristics of patients

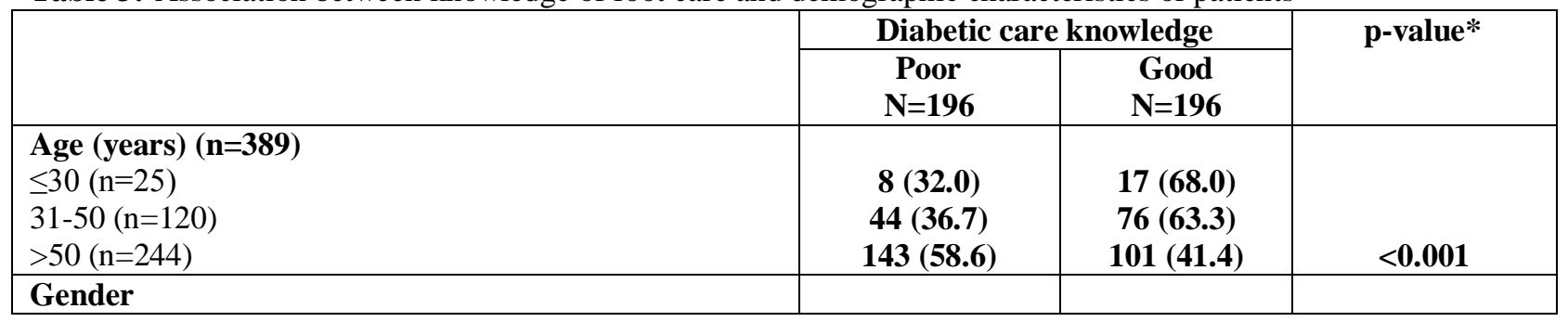




\begin{tabular}{|c|c|c|c|}
\hline $\begin{array}{l}\text { Male }(n=243) \\
\text { Female }(n=149)\end{array}$ & $\begin{array}{c}127(52.3) \\
69(46.3)\end{array}$ & $\begin{array}{c}116(47.7) \\
80(53.7)\end{array}$ & 0.252 \\
\hline $\begin{array}{l}\text { Nationality }(\mathbf{n}=\mathbf{3 8 1}) \\
\text { Saudi }(\mathrm{n}=328) \\
\text { Non-Saudi }(\mathrm{n}=53)\end{array}$ & $\begin{array}{c}162(49.4) \\
28(52.8)\end{array}$ & $\begin{array}{c}166(50.6) \\
25(47.2)\end{array}$ & 0.642 \\
\hline $\begin{array}{l}\text { Occupation } \\
\text { Professionals }(\mathrm{n}=95) \\
\text { Students }(\mathrm{n}=15) \\
\text { Military }(\mathrm{n}=15) \\
\text { Retired }(\mathrm{n}=106) \\
\text { Manual }(\mathrm{n}=35) \\
\text { Not working }(\mathrm{n}=94)\end{array}$ & $\begin{array}{c}44(46.3) \\
5(33.3) \\
9(60.0) \\
59(55.7) \\
13(37.1) \\
49(52.1) \\
\end{array}$ & $\begin{array}{c}51(53.7) \\
10(66.7) \\
6(40.0) \\
47(44.3) \\
22(62.9) \\
45(47.9) \\
\end{array}$ & 0.251 \\
\hline $\begin{array}{l}\text { Education } \\
\text { Illiterate }(n=72) \\
\text { Primary }(n=74) \\
\text { Intermediate }(n=47) \\
\text { Secondary }(n=67) \\
\text { University }(n=108) \\
\text { Postgraduate }(n=23)\end{array}$ & $\begin{array}{c}47(65.3) \\
40(54.1) \\
22(46.8) \\
38(56.7) \\
45(41.7) \\
3(13.0)\end{array}$ & $\begin{array}{l}25(34.7) \\
34(45.9) \\
25(53.2) \\
29(43.3) \\
63(58.3) \\
20(87.0)\end{array}$ & $<0.001$ \\
\hline
\end{tabular}

* Chi-square test

Table 4:-Association between knowledge of foot care and diabetes-related characteristics of patients

\begin{tabular}{|c|c|c|c|}
\hline & \multicolumn{2}{|c|}{ Diabetic care knowledge } & \multirow{2}{*}{ p-value } \\
\hline & $\begin{array}{c}\text { Poor } \\
\text { N=196 }\end{array}$ & $\begin{array}{c}\text { Good } \\
\mathbf{N}=196\end{array}$ & \\
\hline $\begin{array}{l}\text { Age of diabetes onset in years }(\mathbf{n}=\mathbf{3 8 5}) \\
\leq 10(\mathrm{n}=28) \\
11-20(\mathrm{n}=30) \\
>20(\mathrm{n}=327)\end{array}$ & $\begin{array}{c}10(35.7) \\
9(30.0) \\
176(53.8)\end{array}$ & $\begin{array}{r}18(64.2) \\
21(70.0) \\
151(46.2)\end{array}$ & 0.011 \\
\hline $\begin{array}{l}\text { Type of diabetes }(\mathbf{n}=\mathbf{3 8 6}) \\
\text { Type } I(n=45) \\
\text { Type II }(n=201) \\
\text { Unknown }(n=140\end{array}$ & $\begin{array}{l}12(26.7) \\
97(48.3) \\
83(60.0)\end{array}$ & $\begin{array}{c}33(73.3) \\
104(51.7) \\
56(40.0)\end{array}$ & $<0.001$ \\
\hline $\begin{array}{l}\text { Regular compliance with diabetic clinic/center }(\mathbf{n}=\mathbf{3 8 9}) \\
\text { Yes }(\mathrm{n}=253) \\
\text { No }(\mathrm{n}=136)\end{array}$ & $\begin{array}{c}111(43.9) \\
84(61.8)\end{array}$ & $\begin{array}{c}142(56.1) \\
52(38.2)\end{array}$ & $<0.001$ \\
\hline $\begin{array}{l}\text { Adherence to anti-diabetics } \\
\text { Yes }(n=341 \\
\text { No }(n=51)\end{array}$ & $\begin{array}{c}162(47.5) \\
34(33.3)\end{array}$ & $\begin{array}{c}179(52.5) \\
17(33.3)\end{array}$ & 0.011 \\
\hline $\begin{array}{l}\text { History of foot injury lasts for 3-4 weeks } \\
\text { Yes }(n=168) \\
\text { No }(n=224)\end{array}$ & $\begin{array}{c}82(48.8) \\
114(50.9)\end{array}$ & $\begin{array}{c}86(51.2) \\
110(49.1)\end{array}$ & 0.683 \\
\hline $\begin{array}{l}\text { History of toe/foot/lower limb amputation } \\
\text { Yes }(\mathrm{n}=82) \\
\text { No }(\mathrm{n}=310)\end{array}$ & $\begin{array}{c}44(53.7) \\
152(49.0)\end{array}$ & $\begin{array}{c}38(46.3) \\
158(51.0)\end{array}$ & 0.456 \\
\hline
\end{tabular}




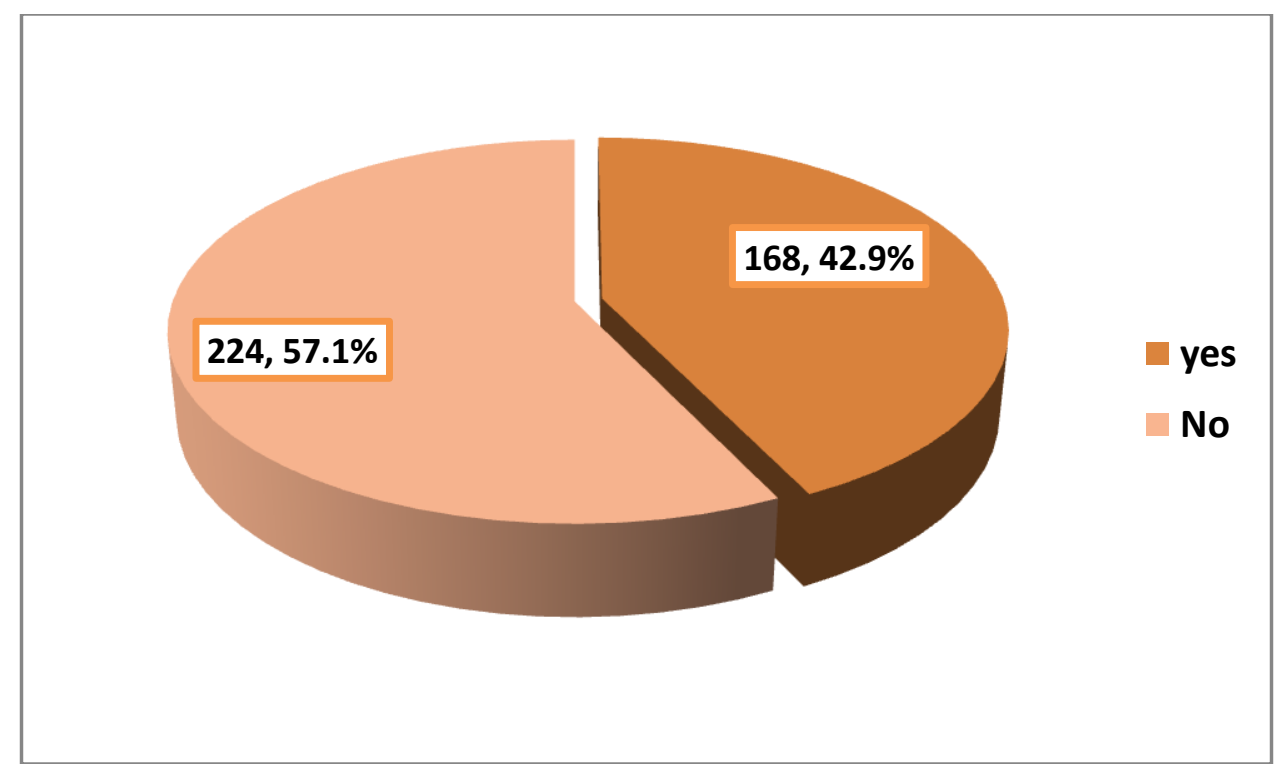

Figure 1:- History of feet wound lasted 3-4 weeks among diabetic patients

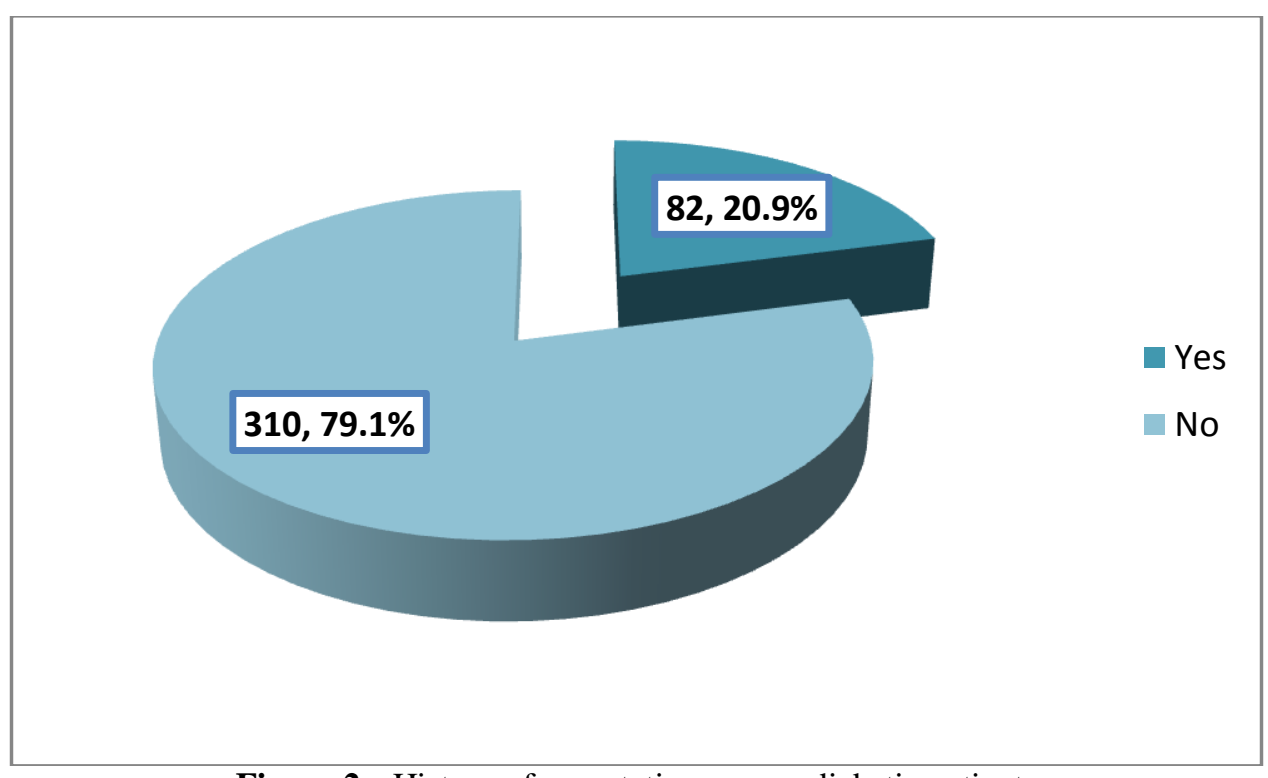

Figure 2:- History of amputation among diabetic patients 


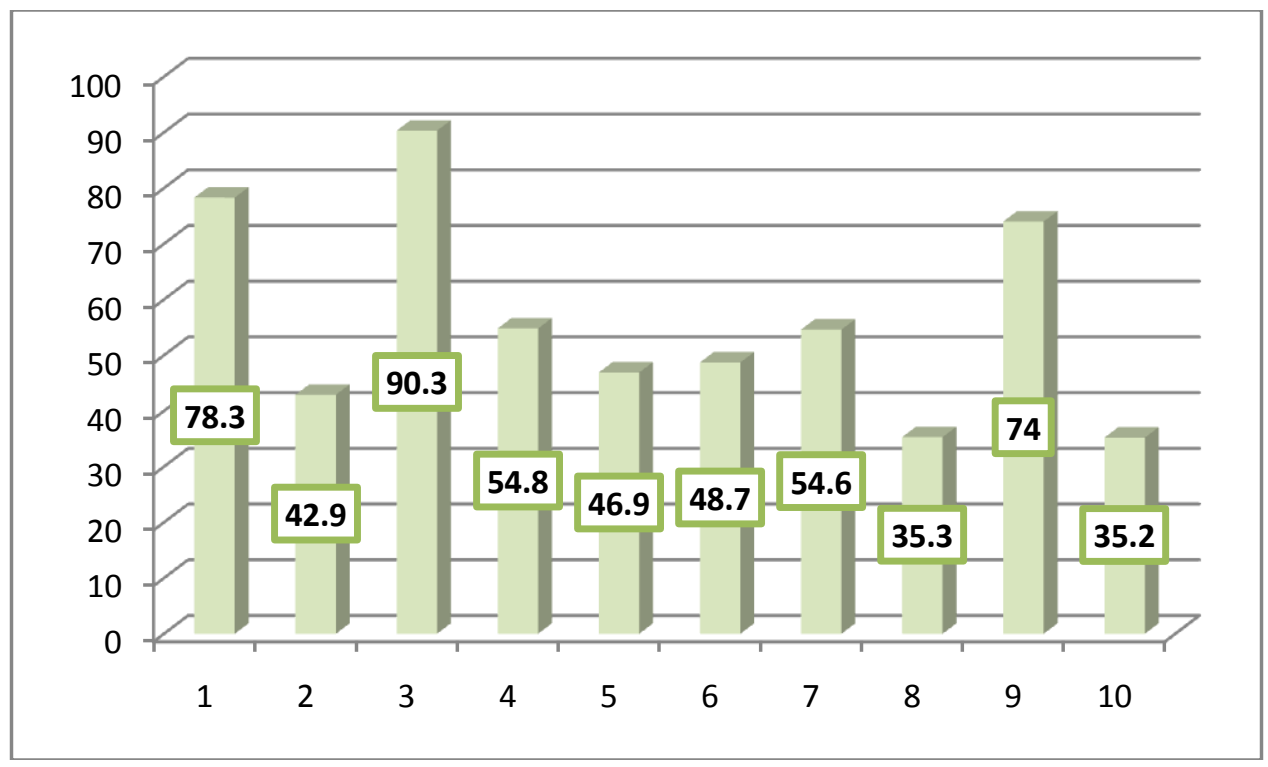

1: Ability to reach the sole of the foot

2: Daily foot examination

3: Washing foot daily

4: Using warm water to wash feet

5: Drying the feet after washing with clean towel

6: Sitting with the feet crossed

7: Using the cream to moisturize the feet

8: Using the cream to moisturize between toes

9: Self cutting of the toe nails

10: Way of cutting the nails

Figure 3:- Diabetic foot care knowledge of 431 diabetic patients

\section{Discussion:-}

In the current study, the mean score of knowledge was 5.6 out of $10(56 \%)$. In a study conducted by Al-Juaid in Taif, Saudi Arabia (2005), ${ }^{7}$ a main knowledge score of $66 \%$ has been reported. In Najran, Saudi Arabia the main knowledge score was 6.5 out of $11(60 \%) .{ }^{8}$ In USA, Southeastern State, the main score of knowledge of a group of diabetic patients without foot ulcer was 13.75 out of $20(68 \%)$ whereas it was 13.88 out of 20 among those with foot ulcer $(69.4 \%){ }^{9}$

In the current study, younger patients were more knowledgeable than older patients. The same has been reported by Al-Juaid in another previous Saudi study.7This could be attributed to the fact that, younger patients were healthier and they can take care of themselves.

In accordance with other syudies, ${ }^{7,10,11}$ higher educated patients were more knowledgeable than others. The knowledge of appropriate foot care has been suggested to be positively influenced by patient education which in turn reduces the risk of foot ulceration and amputation in high-risk diabetics. ${ }^{12}$ The association between education and knowledge may be due to the fact that, educated patient were able to read and understand some of educational supportive materials and also use information technology to obtain more information about the disease. In addition, in a study conducted in India, it was concluded that low knowledge scores were common with poor formal education, thus confirming relationship between education and knowledge. ${ }^{13}$ Role of formal/school education is further confirmed by a study from Italy where the presence of foot complications was correlated with cigarette smoking, insulin treatment, and low levels of school education. ${ }^{14}$

Patients who regularly compliant with diabetic clinics visits and anti-diabetics were more knowledgeable regarding diabetic foot. This could be attributed to the fact that patients usually got their information from primary care centers sources which help them to be more compliant with anti-diabetics and also more knowledgeable of foot care. 
Therefore, health education is an essential task in primary health care centers as well it is one of the important task and responsibility of primary health care physicians.

Type 1 diabetic patients in the present survey reported better foot careknowledge than those of type 2 . This could be attributed to the fact that type 1 diabetes is more associated with complications including diabetic foot. ${ }^{15}$ Therefore, they had to be more knowledgeable about it.

Patient`s gender has shown no relationship regarding knowledge and practices of foot care whereas in another study conducted in India, low scores for foot care knowledge were more common in women (78.5\%) than in men (62.5\%). However this can be explained on the basis that in that particular study, there were more women with low educational status. ${ }^{16}$

In conclusion, Knowledge of diabetic foot care in Makkah is moderate (56\%), younger, more educated, type 1 diabetic patients and those who attended diabetic clinics regularly and being more compliant with anti-diabetics were more knowledgeable. Heath education programs are recommended particularly to older and less educated patients. In addition, patients should be encouraged to attend diabetic clinics regularly.

The present research has some important limitations. First, our sample was recruited from attendees of major hospitals in Makkah ignoring those attending primary health care centers, which limits the representative of the sample. The used tool was not subjected to tests of validity and reliability. Despite of that, our study has been able to determine the knowledge of foot care among diabetic patients in Makkah, Saudi Arabia and identifying factors associated with that knowledge.

\section{References:-}

1. Wild S, Roglic G, Green A, Sicree R, King H. Global prevalence of diabetes: Estimates for the year 2000 and projections for 2030. Diabetes Care. 2004;27:1047-53

2. Margolis DJ, Malay DS, Hoffstad OJ, Leonard CE, MaCurdy T, López de Nava K, et al. Prevalence of diabetes, diabetic foot ulcer, and lower extremity amputation among Medicare beneficiaries, 2006 to 2008: Data Points \#1. Data Points Publication Series [Internet]. Rockville (MD): Agency for Healthcare Research and Quality (US);

2011-.

2011 Feb 17. Available at: https://www.ncbi.nlm.nih. gov/ books/ NBK63602/\#dp1.s5

3. Alqurashi KA, Aljabri KS, Bokhari SA. Prevalence of diabetes mellitus in a Saudi community. Ann Saudi Med. 2011 Jan-Feb; 31(1): 19-23.

4. Wu SC, Driver VR, Wrobe JS, Armstrong DG. Foot ulcers in the diabetic patient, prevention and treatment. Vasc Health Risk Manag. 2007 Feb; 3(1): 65-76.

5. Ahmed AA, Elsharief E, Alsharief A. The diabetic foot In the Arab world. The Journal of Diabetic Foot Complications 2011; 3(3): 55-61

6. Boulton AJM. The diabetic foot: grand overview, epidemiology and pathogenesis Diabetes Metab Res Rev 2008; 24(Suppl 1): S3-S6.

7. Al-Juaid BM. Self care knowledge and practice among type 2 diabetic patients. A dissertation submitted for the Joint program of Family and Community Medicine, Jeddah, Saudi Arabia, 2005

8. Khan LA, Khan SA. Level of knowledge and self-car in diabetics in a community hospital in Najran. Annals of Saudi Medicine 2000;20(3-4):300-302

9. Neil JA. Assessing foot care knowledge in a rural population with diabetes. ostomyWoung Manage 2002 Jan;48(1):50-6

10. Desalu OO, Salawu FK, Jimoh AK, Adekoya AO, Busari OA, Olokoba AB. Diabetic foot care: Self reported knowledge and practice among patients attending three teriary hospitals in Nigeria. Ghana Medical Journal 2011;45(2):60-65

11. Hasnain S, Sheikh NH. Knowledge and practices regarding foot care in diabetic patients visiting diabetic clinic in Jinnah Hospital, Lahore. JPMA 2009; 59(10):687-690

12. Singh N, Armstrong DG, Lipsky BA. Preventing foot ulcers in patients with diabetes. JAMA 2005; 293: 217 228.

13. Viswanathan V, Shobhana R, Snehalatha C, Seena R, Ramachandran A. Need for education on foot care in diabetic patients in India. J Assoc Physicians India 1999; 47: 1083-5. 
14. De Beradis G, Pellegrini F, Fanciosi M, Belfiglo M, Di Nardo B, Greenfield S, et al. Are Type 2 diabetic patients offered adequate foot care? The role of physician and patient characteristics. J Diabetes Complications 2005; 19: 319-27.

15. Al-Rubeaan K, Al Derwish M, Ouizi S, Youssef AM, Subhani SN, Ibrahim HM, Alamri BN. Diabetic Foot Complications and Their Risk Factors from a Large Retrospective Cohort Study. PLoS One. 2015; 10(5): e0124446.

16. Viswanathan V, Shobhana R, Snehalatha C, Seena R, Ramachandran A. Need for education on foot care in diabetic patients in India. J Assoc Physicians India 1999; 47: 1083-5. 